\title{
Activation of Nuclear Factor- $\kappa B$ and Its Suppression by Dexamethasone in Polymorphonuclear Leukocytes: Newborn Versus Adult
}

\author{
IVANA VANCUROVA, PATRICIA BELLANI, AND DENNIS DAVIDSON \\ Division of Neonatal-Perinatal Medicine, Schneider Children's Hospital, Long Island Jewish Medical \\ Center, The Long Island Campus for the Albert Einstein College of Medicine, New Hyde Park, New York
} 11040, U.S.A.

\begin{abstract}
Polymorphonuclear leukocytes (PMN) of the newborn, to a greater extent than those of the adult, have the ability to amplify PMN recruitment to an inflammatory site by their own release of IL-8, and this process is inhibited by dexamethasone. The aim of the present study was to determine whether the regulation of nuclear factor- $\kappa \mathrm{B}(\mathrm{NF}-\kappa \mathrm{B})$ could explain the previous observations. NF- $\kappa \mathrm{B}$ is a transcription factor pivotal for expression of genes encoding inflammatory cytokines such as IL-8, but NF- $\kappa \mathrm{B}$ has not been previously studied in the PMN of the newborn. $\mathrm{NF}-\kappa \mathrm{B}$ activation was measured by an electrophoretic mobility shift assay in nuclear extracts prepared from PMN isolated from adults and cord blood from newborns. Two distinct molecular forms of NF- $\kappa$ B were identified after tumor necrosis factor- $\alpha$ stimulation; this included the previously characterized $\mathrm{p} 50 / 65$ heterodimer and a newly identified p50/50 homodimer. Both $\mathrm{NF}-\kappa \mathrm{B}$ dimers were activated by tumor necrosis factor $-\alpha$ to significantly higher levels in the neutrophil of the newborn versus adult. An additional new finding was that pretreatment of
\end{abstract}

\section{ABSTRACT}

PMN with dexamethasone $\left(10^{-7} \mathrm{M}\right.$, therapeutic range) inhibited activation of both NF- $\kappa \mathrm{B}$ complexes in both the newborn and the adult PMN. We conclude that the increased activation of NF- $\kappa \mathrm{B}$ by the PMN of the newborn may play an important role in neonatal inflammatory reactions. Eventually, specific targeting of $\mathrm{NF}-\kappa \mathrm{B}$ activation in the neutrophil may be an effective molecular approach for the treatment of neutrophil-mediated disorders in the newborn. (Pediatr Res 49: 257-262, 2001)

\section{Abbreviations}

BPD, bronchopulmonary dysplasia

DEX, dexamethasone

EMSA, electrophoretic mobility shift assay

IKK, I $\kappa \mathrm{B}$ kinase

$\mathbf{I} \boldsymbol{k} \mathbf{B}$, inhibitor $\kappa \mathrm{B}$

$\mathbf{N F}-\boldsymbol{\kappa} \mathbf{B}$, nuclear factor $-\boldsymbol{\kappa} \mathrm{B}$

NIK, NF- $\kappa \mathrm{B}$-inducing kinase

TNF, tumor necrosis factor- $\alpha$
Polymorphonuclear leukocytes (PMN or neutrophils) have been implicated in the pathogenesis of several acute and chronic lung diseases such as acute respiratory distress syndrome and BPD $(1,2)$. During this process, neutrophils recruited into the lung release mediators that are injurious, including proteolytic enzymes, toxic oxygen radicals, and arachidonic acid metabolites (2). However, it has become evident that neutrophils are more than inflammatory effector cells; they have the ability to amplify the inflammatory response by the release of cytokines (3-7). Recent work from our laboratory has demonstrated that the neutrophil of the newborn releases IL-8 in quantities sufficient for the chemotaxis of other neu-

Received April 19, 2000; accepted October 13, 2000.

Correspondence: Ivana Vancurova, Ph.D., Long Island Jewish Medical Center, Research Building B-49, 270-05 76th Avenue, New Hyde Park, NY 11040, U.S.A.

Supported by Faculty Research Award from the Long Island Jewish Medical Center to I.V trophils, that this process is more intense for the newborn versus the adult, and that neutrophil IL- 8 release is inhibited by DEX (8).

$\mathrm{NF}-\kappa \mathrm{B}$ is one of the critical regulatory proteins that control expression of inflammatory genes, including IL- $\beta$, IL- 8 , and TNF- $\alpha(9-11)$. The NF- $\kappa$ B proteins (p50 NF- $\kappa$ B1, p65/Rel A, $\mathrm{c}-\mathrm{Rel}, \mathrm{NF}-\kappa \mathrm{B} 2 / \mathrm{p} 52$, and Rel B) are retained in the cytoplasm through their association with the inhibitory protein $\mathrm{I} \kappa \mathrm{B}-\alpha$. After cell stimulation, NF- $\kappa \mathrm{B}$ translocates to the nucleus where it activates gene transcription (9-11). However, expression and activation of the individual NF- $\kappa \mathrm{B}$ subunits is cell-specific and appears to be developmentally regulated (12).

Because the knowledge that neutrophils are an important source of cytokines is relatively new, the molecular mechanisms regulating cytokine expression in these cells have only begun to be investigated (13-16); there are no previous studies in the newborn. The aims of the present study were to deter- 
mine 1 ) whether there are differences in NF- $\kappa \mathrm{B}$ activation in neutrophils of the newborn versus adult that parallel our previous studies involving IL-8 and 2) whether DEX inhibits $\mathrm{NF}-\kappa \mathrm{B}$ activation in the neutrophil.

\section{METHODS}

Antibodies and reagents. Purified polyclonal antibodies to human p50 (sc-7178X), c-Rel (sc-70X), and Bcl-3 (sc-185) and recombinant human $\mathrm{I} \kappa \mathrm{B}-\alpha$ protein (sc-4094) were purchased from Santa Cruz Biotechnology (Santa Cruz, CA, U.S.A.). Polyclonal antibody to p65 (SA-171) was obtained from Biomol (Plymouth Meeting, PA, U.S.A.). Ficoll-Paque PLUS, Dextran T-500, T4 polynucleotide kinase, poly (dI-dC), and Sephadex G25 spin columns were purchased from Pharmacia (Piscataway, NJ, U.S.A.). Hanks' balanced salt solution, RPMI 1640 medium, and endotoxin-tested heat-inactivated FCS were obtained from Life Technologies (Grand Island, NY, U.S.A.). Escherichia coli expressed purified recombinant human TNF- $\alpha$ was purchased from R\&D Systems (Minneapolis, MN, U.S.A.). Acetylated BSA, Nonidet 40 (NP-40), phenylmethylsulfonyl fluoride (PMSF), DTT, and the protease inhibitor cocktail for mammalian cell extracts (P-8340) containing pepstatin A, bestatin, leupeptin, aprotinin, 4-(2-aminoethyl)benzenesulfonyl fluoride (AEBSF), and trans-epoxysuccinyl1-leucylamido(4-guanidino)butane (E-64) were obtained from Sigma Chemical Co. (St. Louis, MO, U.S.A.). $\left[{ }^{32} \mathrm{P}\right]$ ATP was purchased from NEN (Boston, MA, U.S.A.).

Blood collection. Fresh whole blood $(32 \mathrm{~mL})$ was obtained from healthy adult human volunteers or from the umbilical vein of the placentas from healthy full-term infants immediately after delivery by elective cesarean section without general anesthesia. Blood was collected in heparinized preservativefree tubes. The present study was approved by the Human Subjects Review Committee of Long Island Jewish Medical Center.

Neutrophil isolation and culture. Neutrophils were isolated under endotoxin-free conditions using Ficoll-Paque centrifugation followed by dextran sedimentation and hypotonic lysis of residual erythrocytes as described previously (17). The cell preparations contained more than $98 \%$ neutrophils and were more than $99 \%$ viable as determined by trypan-blue exclusion. Purified neutrophils were resuspended in RPMI 1640 supplemented with $10 \%$ low-endotoxin FCS at a final concentration of $5 \times 10^{6}$ cells $/ \mathrm{mL}$ and incubated at $37^{\circ} \mathrm{C}$ in polypropylene tubes with gentle agitation. Cells were allowed to equilibrate for $15 \mathrm{~min}$ at $37^{\circ} \mathrm{C}$ before stimulation with TNF- $\alpha(2 \mathrm{ng} / \mathrm{mL})$ for the indicated times. In DEX studies, cells were pretreated (1 $\left.\mathrm{h}, 37^{\circ} \mathrm{C}\right)$ with or without $\operatorname{DEX}\left(10^{-7} \mathrm{M}\right)$ followed by stimulation with TNF $(2 \mathrm{ng} / \mathrm{mL})$ for $30 \mathrm{~min}$ at $37^{\circ} \mathrm{C}$.

Nuclear extract preparation. Nuclear extracts were prepared from $5 \times 10^{6}$ cells by using a modification of the method of Dignam et at (18). Briefly, the pelleted cells were resuspended in $300 \mu \mathrm{L}$ of hypotonic buffer (buffer A: $10 \mathrm{mM}$ HEPES, pH 7.5, $10 \mathrm{mM} \mathrm{KCl,} 3 \mathrm{mM} \mathrm{NaCl}, 3 \mathrm{mM} \mathrm{MgCl}_{2}, 1$ mM EDTA, 1 mM EGTA, 2 mM DTT, 2 mM PMSF) containing protease inhibitor cocktail and placed on ice for $15 \mathrm{~min}$. [This is a protease inhibitor cocktail for mammalian cell extracts containing pepstatin A, bestatin, leupeptin, aprotinin, AEBSF, and E-64 obtained from Sigma Chemical Co. (P8340 ) and used in concentrations $60 \mu \mathrm{L} / 5 \times 10^{6}$ cells.] After the addition of $0.1 \mathrm{vol}$ of $10 \% \mathrm{NP}-40$, the cells were vortexed $(10 \mathrm{~s})$ and immediately centrifuged at $500 \times \mathrm{g}$ for $10 \mathrm{~min}$ at $4^{\circ} \mathrm{C}$. The supernatants were discarded, and the pellets were washed in $200 \mu \mathrm{L}$ of buffer A and recentrifuged. The pelleted nuclei were resuspended in $50 \mu \mathrm{L}$ of ice-cold nuclear buffer (NE buffer: $20 \mathrm{mM}$ HEPES, $\mathrm{pH} 7.5,25 \%$ glycerol, $500 \mathrm{mM}$ $\mathrm{KCl}, 1 \mathrm{mM} \mathrm{MgCl} 2,1 \%$ NP-40, 1 mM EDTA, 2 mM DTT, 2 $\mathrm{mM}$ PMSF) containing the protease inhibitor cocktail $(60 \mu \mathrm{L} / 5$ $\times 10^{6}$ cells). After a 20 -min incubation on ice (with occasional mixing), the samples were centrifuged $(14,000 \times g, 15 \mathrm{~min}$, $4^{\circ} \mathrm{C}$ ), and the resulting supernatants (nuclear extracts) were aliquoted and stored at $-80^{\circ} \mathrm{C}$. Protein concentration was measured using the Pierce Coomassie plus protein assay kit (Pierce, Rockford, IL, U.S.A.).

EMSA. The oligonucleotide used as a probe for EMSA was a 42-bp double-stranded construct (5'-TTGTTACAAGGG GACTTTCCGCTGGGGACTTTCCAGGGAGGC-3') containing two tandemly repeated NF- $\kappa \mathrm{B}$ binding sites (underlined). Mutant oligonucleotide used for competition studies was 5'TTGTTACAATCTCACTTTCCGCTTCTCACTTTCCAGGG AGGC- ${ }^{\prime}$. End labeling was accomplished by treatment with T4 kinase in the presence of $\gamma-\left[{ }^{32} \mathrm{P}\right] \mathrm{ATP}$, and the labeled oligonucleotide was purified on a Sephadex G-25 column as described elsewhere (19).

Nuclear extracts (containing 5-7 $\mu \mathrm{g}$ of protein, $8 \times 10^{5}$ cell equivalent, in $7-10 \mu \mathrm{L}$ ) were incubated (20 min at room temperature) with 5-10 fmol of radiolabeled oligonucleotide (approximately $70,000 \mathrm{cpm}$ ) in $20 \mu \mathrm{L}$ of binding buffer (20 $\mathrm{mM}$ Tris-Cl, pH 7.5, $150 \mathrm{mM} \mathrm{KCl}, 1 \mathrm{mM}$ EDTA, 1 mM DTT, $0.1 \%$ NP-40, $6 \%$ glycerol) supplemented with $20 \mu \mathrm{g}$ acetylated BSA and $2 \mu \mathrm{g}$ poly (dI-dC). For competition or supershift experiments, binding reactions were performed in the presence of 30-M excess of unlabeled oligonucleotide or $1 \mu \mathrm{g}$ of specific polyclonal antibody, respectively, and incubated $15 \mathrm{~min}$ at room temperature before adding ${ }^{32} \mathrm{P}$-labeled oligonucleotide. The resulting complexes were resolved on $5 \%$ nondenaturing polyacrylamide gels that had been prerun at $100 \mathrm{~V}$ for $30 \mathrm{~min}$ in $0.5 \times$ TBE buffer $(45 \mathrm{mM}$ Tris, $45 \mathrm{mH}$ boric acid, and $1 \mathrm{mM}$ EDTA, pH 8.0). Electrophoresis was conducted at $180 \mathrm{~V}$ for $2.5 \mathrm{~h}$. After electrophoresis, gels were transferred to Whatman DE-81 paper, dried, and exposed to autoradiographic film (Kodak Biomax MS) with intensifier screen at $-80^{\circ} \mathrm{C}$. Each gel was exposed to the film for different lengths of time to generate series of images with different intensities. Only the exposures that fell within the linear response of the film were used for digital quantification using image analysis software (UN-SCAN-IT gel Version 5.1 from Silk Scientific, Orem, UT, U.S.A.).

Statistical analysis. Data were expressed as mean \pm SEM. The Mann-Whitney test was used to compare TNF-induced activation of NF- $\kappa \mathrm{B}$ between neutrophils of the newborn versus adult. A $p$ value $<0.05$ was considered significant. Data were analyzed by using an InStat software package (GraphPAD, San Diego, CA, U.S.A.). 


\section{RESULTS}

Characterization of molecular forms of NF-кB in neutrophils of the newborn. To analyze the molecular forms of $\mathrm{NF}-\kappa \mathrm{B}$ in newborn neutrophils, we used EMSA, with an $\mathrm{NF}-\kappa \mathrm{B}$ oligonucleotide containing two tandemly repeated $\mathrm{NF}-\kappa \mathrm{B}$ binding sites. Incubation of a radiolabeled NF- $\kappa \mathrm{B}$ oligonucleotide with nuclear extracts of TNF-stimulated neutrophils resulted in reduced mobility of two NF- $\kappa \mathrm{B}$ binding complexes (Fig. 1, lane 1). To confirm the specificity of the DNA-protein interaction, we performed competition studies with unlabelled oligonucleotides. Addition of a 30-fold excess of unlabeled wild-type NF- $\kappa \mathrm{B}$ oligonucleotide resulted in complete disappearance of both complexes (lane 2), whereas unlabeled mutant oligonucleotide did not affect either band (lane 3).

To analyze the subunit composition of these two complexes, we performed a supershift assay using polyclonal antibodies against p50, p65, and c-Rel subunits of NF- $\kappa$ B. Antibody to p50 supershifted both bands (Fig. 1, lane 4), whereas the antibody to p65 supershifted only the slower migrating band (lane 5). Antibody to c-Rel (lane 6) failed to bind to either complex. Moreover, both NF- $\kappa \mathrm{B}$ complexes were able to bind the inhibitory protein $\mathrm{I} \kappa \mathrm{B}-\alpha$ in vitro (lane 7$)$. Figure 1 represents four independent experiments; the same results were also obtained with neutrophils from the adult (data not shown). These results indicate that the slower migrating NF- $\kappa \mathrm{B}$ complex in TNF-stimulated neutrophils consists of the previously

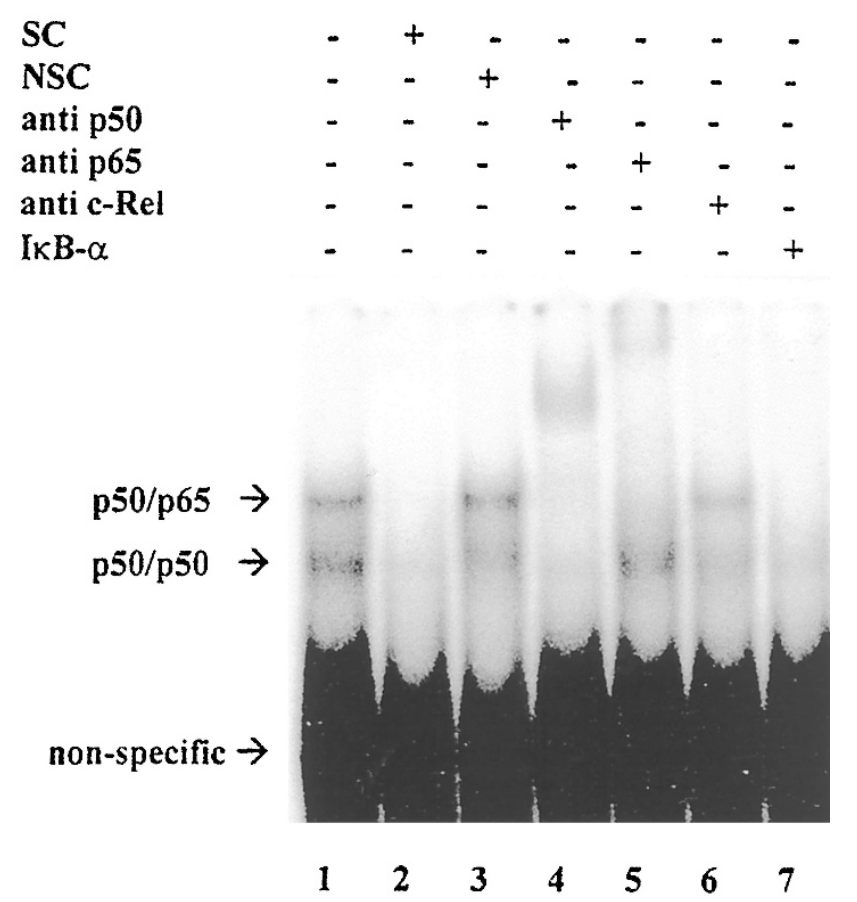

Figure 1. EMSA and supershift analysis of NF- $\kappa$ B complexes identified in nuclear extracts from TNF-stimulated human neutrophils. Nuclear extracts were incubated with NF- $\kappa \mathrm{B}$-specific DNA probe alone (lane 1) or in the presence $(+)$ of $30-\mathrm{M}$ excess of a specific competitor (SC) oligonucleotide (lane 2) or a nonspecific competitor (NSC) oligonucleotide (lane 3). Antibodies used in supershift assays included antibodies to p50 (lane 4), p65 (lane 5), and c-Rel (lane 6). Lane 7 shows incubation of nuclear extract with $1 \mu \mathrm{g}$ of recombinant protein $\mathrm{I} \kappa \mathrm{B}-\alpha$. This experiment is representative of four. characterized p50/65 heterodimer (13-15), whereas the faster migrating NF- $\kappa \mathrm{B}$ complex represents a newly identified $\mathrm{p} 50 / 50$ homodimer.

Activation of $N F-\kappa B$ in neutrophils: newborn versus adult. To investigate activation of the newly identified p50/50 homodimer as well as of the p50/65 heterodimer, neutrophils from newborn and adult were stimulated with TNF, and NF- $\kappa \mathrm{B}$ DNA binding activities were analyzed in nuclear extracts by EMSA. For both the newborn and the adult, both the p50/65 heterodimers and the p50/50 homodimers were induced by TNF within $15 \mathrm{~min}$, the maximal activation being achieved after 30 -min stimulation. Figure 2 is a representative EMSA ( $n$ $=7$ ) illustrating NF- $\kappa \mathrm{B}$ activation in neutrophils from newborn and adult stimulated 30 min with TNF. As expected, only little NF- $\kappa$ B DNA binding activity was detected in unstimulated neutrophils. This activity consisted mainly of the p50/50 homodimers; however, after longer film exposures, the p50/65 heterodimer also became visible.

Significantly higher inducibility of both the p50/65 heterodimer and the p50/50 homodimer was detected in TNFstimulated neutrophils of the newborn versus adult (Fig. 2). Densitometric analysis of scanned images revealed that in the neutrophil of the newborn, the DNA binding activity of the p50/65 heterodimer increased at 30 min approximately 6-fold ( samples at $\mathrm{t}=30$ min were compared with samples at $\mathrm{t}=0$ min, analyzed on the same gel) (Fig. 3). In contrast, in the neutrophils from adults, the DNA binding activity of the p50/65 heterodimer increased only 2.5-fold (samples at $\mathrm{t}=30$ min TNF stimulation were compared with the control samples at $\mathrm{t}=0$ ). The $\mathrm{p} 50 / 50$ homodimer was activated approximately 2.8-fold in the newborn and 1.5-fold in the adult.

Activation of $N F-\kappa B$ in human neutrophils is inhibited by $\boldsymbol{D E X}$. To test the hypothesis that DEX suppresses activation of $\mathrm{NF}-\kappa \mathrm{B}$ in human neutrophils, neutrophils from both adult and newborn were preincubated $1 \mathrm{~h}$ at $37^{\circ} \mathrm{C}$ with $\operatorname{DEX}\left(10^{-7} \mathrm{M}\right.$, therapeutic range) before stimulation with TNF $(2 \mathrm{ng} / \mathrm{mL})$ for $30 \mathrm{~min}$, and nuclear extracts were analyzed for NF- $\kappa \mathrm{B}$ DNA

\section{$\begin{array}{lllll}\text { Time (min) } & \mathbf{0} & \mathbf{3 0} & \mathbf{0} & \mathbf{3 0}\end{array}$}

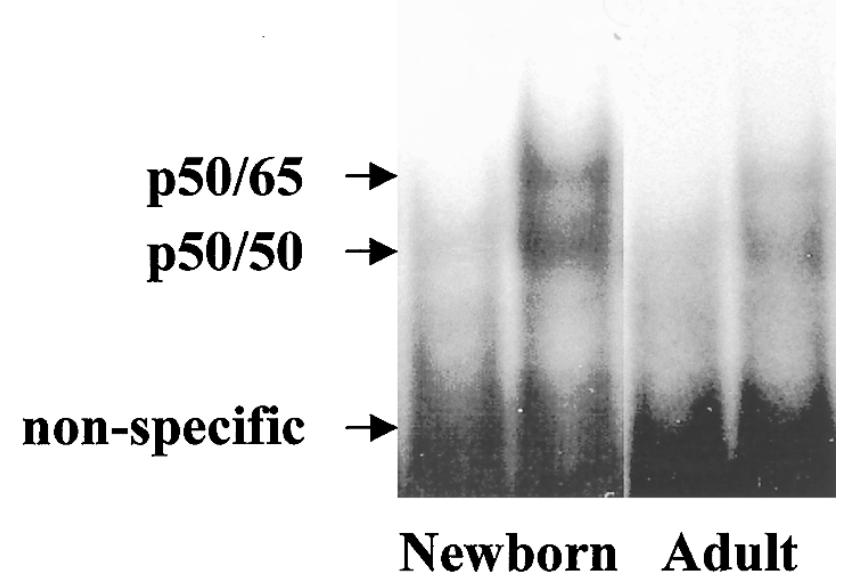

Figure 2. Representative EMSA analysis of NF- $\kappa$ B DNA binding in human neutrophils isolated from newborns and adults and stimulated $30 \mathrm{~min}$ with TNF. 


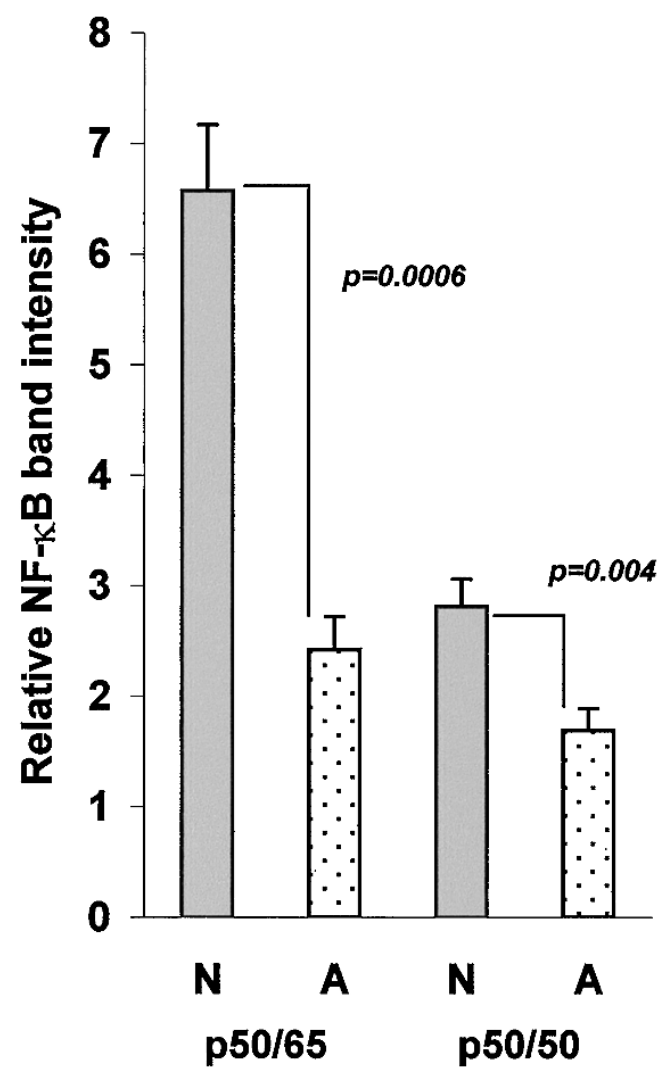

Figure 3. Densitometric evaluation (mean \pm SEM) of NF- $\kappa$ B DNA binding activities in the neutrophils from the newborn $(N, n=7)$ and adult $(A, n=7)$ at 30-min stimulation with TNF. Samples (nonstimulated and stimulated 30 min with TNF) were analyzed by EMSA (on the same gel), and the magnitude of the DNA binding activity at $\mathrm{t}=30 \mathrm{~min} v s \mathrm{t}=0 \mathrm{~min}$ was evaluated by densitometry.

binding activity by EMSA. As shown in Figure 4, pretreatment with DEX (lane 3) reduced activation of both NF- $\kappa \mathrm{B}$ complexes in TNF-stimulated neutrophils (lane 2). Densitometric analysis revealed that activation of p50/65 heterodimer was inhibited by $50 \pm 15 \%(n=3)$ in the adult and by $48 \pm 12 \%$ $(n=3)$ in the newborn. The p50/50 homodimer was inhibited by $48 \pm 12 \%(n=3)$ in the adult, and by $35 \pm 9 \%(n=3)$ in the newborn.

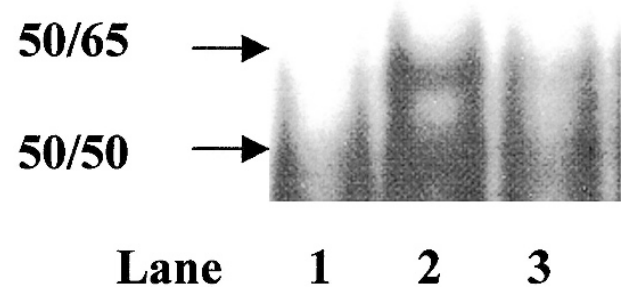

Figure 4. Inhibition of $\mathrm{p} 50 / 65$ and $\mathrm{p} 50 / 50 \mathrm{NF}-\kappa \mathrm{B}$ activation by DEX. Neutrophils of the newborn were pretreated $\left(1 \mathrm{~h}, 37^{\circ} \mathrm{C}\right)$ with $\operatorname{DEX}\left(10^{-7} \mathrm{M}\right)$ before stimulation with $\mathrm{TNF}\left(2 \mathrm{ng} / \mathrm{mL}, 30 \mathrm{~min}, 37^{\circ} \mathrm{C}\right)$. Lane 1 , control, nonstimulated neutrophils; lane 2, TNF-stimulated neutrophils; lane 3, TNFstimulated neutrophils pretreated with DEX. Results are representative of three independent experiments.

\section{DISCUSSION}

This is the first study that focuses on the activation of the transcription factor NF- $\kappa \mathrm{B}$ in neutrophils of the newborn. $\mathrm{NF}-\kappa \mathrm{B}$ plays a central role in the regulation of gene expression underlying production of inflammatory cytokines, enzymes, and adhesion molecules $(9-11)$. Our results demonstrate for the first time that the faster-migrating NF- $\kappa \mathrm{B}$ complex in TNF-stimulated neutrophils represents a newly identified p50/50 homodimer, whereas the slower migrating complex consists of the previously characterized p50/65 heterodimer (13-15). The $\mathrm{p} 50 / 65$ heterodimer is the classic form of NF- $\kappa \mathrm{B}$ responsible for induction of inflammatory gene production; the cellular function of $\mathrm{p} 50 / 50$ homodimer is not fully understood (12). Recently, hyperinduction of $\mathrm{p} 50 / 50$ homodimers has been associated with a repression of transcriptional activation of inflammatory genes and with the induction of lipopolysaccharide tolerance in monocytes and macrophages (20-23). One may, therefore, speculate that the p50/50 homodimer activation in the neutrophil may counteract an excessive activation of the p50/65 heterodimer and, thus, represent an important antiinflammatory regulatory mechanism.

Previous studies in our laboratory and others have shown that neutrophils of the newborn have increased ability to synthesize inflammatory cytokines IL- 8 and IL- $1 \beta$, respectively $(8,24)$. However, the molecular mechanisms responsible for the increased expression of inflammatory cytokines by neutrophils of the newborn were not studied. Because the promoter regions of both IL- $1 \beta$ and IL-8 contain NF- $\kappa$ B binding regulatory sequences (9-11), we hypothesized that the increased expression of these inflammatory cytokines by neutrophils from the newborn is caused by an increased activation of NF- $\kappa$ B that would lead to increased transcription of these cytokines. In this article, we demonstrate that the neutrophil from the newborn exhibits increased activation of NF- $\kappa \mathrm{B}$ and especially that of p50/65 heterodimer. At present, we do not know the underlying mechanisms responsible for the increased activation of NF- $\kappa \mathrm{B}$ in the neutrophil of the newborn. One of the critical regulatory steps dictating the kinetics of $\mathrm{I} \kappa \mathrm{B}-\alpha$ degradation and NF- $\kappa$ B activation are IKK (consisting of the catalytic subunits IKK- $\alpha$ and $-\beta$ and the regulatory subunit $\gamma$ ) and NIK (25). Therefore, one of the underlying mechanisms responsible for the increased NF- $\kappa$ B inducibility in the neutrophil of the newborn may be the increased activation of IKK and/or NIK. Alternatively, the increased NF- $\kappa$ B inducibility may be caused by altered degradation of I $\kappa \mathrm{B}-\alpha$. Recent studies demonstrate involvement of ubiquitin-like protein SUMO-1 in a reversible modification of $I \kappa \mathrm{B}-\alpha$ and negative regulation of $\mathrm{NF}-\kappa \mathrm{B}$ activation (26). In addition, NF- $\kappa \mathrm{B}$ activation can be regulated at the level of nuclear export of the p50/65 I $\kappa \mathrm{B}-\alpha$ complexes by virtue of nuclear shuttling of $\mathrm{I} \kappa \mathrm{B}-\alpha(26,27)$. Clearly, the regulation of NF- $\kappa \mathrm{B}$ activation is more complex than was originally recognized. More studies are needed to dissect the individual pathways regulating NF- $\kappa \mathrm{B}$ activation in human neutrophils, and studies are currently in progress to identify the exact molecular mechanisms responsible for the increased inducibility of NF- $\kappa \mathrm{B}$ in the neutrophil of the newborn. Interestingly, our results parallel the studies in human $\mathrm{T}$ 
lymphocytes demonstrating increased activation of NF- $\kappa \mathrm{B}$ in the newborn versus adult (28). Given the involvement of $\mathrm{NF}-\kappa \mathrm{B}$ in transcriptional regulation of inflammatory genes $(9-11)$, the increased activation of NF- $\kappa$ B in the newborn may play a key role in neonatal inflammatory and immunologic reactions.

The increased activity of NF- $\kappa \mathrm{B}$ in neonatal neutrophil may also represent an important protective mechanism of the newborn against apoptosis. Recent studies indicate that NF- $\kappa \mathrm{B}$, and particularly the p65-RelA subunit, exhibits also an antiapoptotic function in TNF-induced cell-death pathways in the neutrophil as well as in other cell types $(12,15)$. Interestingly, Allgaier et al. (29) have demonstrated increased resistance of newborn neutrophils to apoptosis compared with those from adults, and they suggested increased expression of antiapoptotic gene(s) in the neutrophils from the newborns.

DEX is an effective but controversial therapy for the safe treatment of chronic lung disease or BPD in newborns (30). An understanding of the mechanism(s) of DEX antiinflammatory function in newborns with BPD is poorly understood. However, it is established that the neutrophil plays an important role in the pathogenesis of BPD (31) and that the production of IL-8 in neutrophils is inhibited by DEX $(8,32)$. Still, there have been no previous studies addressing molecular mechanisms of DEX inhibition of cytokine production in the neutrophil. In this study, we have undertaken the first steps to investigate whether the suppressive effects of DEX on cytokine production in neutrophils are mediated through inhibition of NF- $\kappa$ B activation. We demonstrate for the first time that in both newborn and adult neutrophils, DEX (in therapeutic concentration) inhibits activation of both $\mathrm{p} 50 / 65$ and $\mathrm{p} 50 / 50 \mathrm{NF}-\kappa \mathrm{B}$ complexes. The molecular mechanisms underlying this NF- $\kappa \mathrm{B}$ inhibition by DEX in neutrophils are currently under investigation. Studies from other cell types demonstrated two different mechanisms for the NF- $\kappa$ B inhibition by DEX (33-35). Although in peripheral cells such as monocytes and lymphocytes, glucocorticoids inhibit NF- $\kappa \mathrm{B}$ activation by enhancing the cellular levels of $\mathrm{I} \kappa \mathrm{B}-\alpha(36,37)$, in endothelial and epithelial cells, the repressive effects of glucocorticoids are mediated by direct protein-protein interactions between the activated glucocorticoid receptor and the p65 NF- $\kappa \mathrm{B}$ subunit $(38-41)$.

In summary, results of the present study demonstrate an increased TNF-stimulated inducibility of transcription factor $\mathrm{NF}-\kappa \mathrm{B}$ in the neutrophil of the newborn. In addition, we show that this NF- $\kappa \mathrm{B}$ activation is inhibited by DEX. The increased activation of NF- $\kappa \mathrm{B}$ in the neutrophils of the newborn likely represents the underlying molecular mechanism of the previously reported elevated production of proinflammatory cytokines IL- 8 and IL- $1 \beta$ by the newborn $(8,24)$. In addition, our results may be related to the increased resistance of the neutrophil of the newborn to apoptosis (29). Further studies are needed to identify the exact molecular mechanisms responsible for the increased activation of NF- $\kappa \mathrm{B}$ and its inhibition by DEX in the newborn.

Acknowledgment. The authors thank Veronika Miskolci for excellent technical assistance.

\section{REFERENCES}

1. Malech HL, Gallin JI 1987 Neutrophils in human diseases. N Engl J Med 317:687694

2. Sibille Y, Renolds HY 1990 Macrophages and polymorphonuclear neutrophils in lung defense and injury. Am Rev Respir Dis 141:471-501

3. Tiku K, Tiku ML, Skosey JL 1986 Interleukin-1 production by human polymorphonuclear neutrophils. J Immunol 136:3677-3685

4. Dubravec DB, Spriggs DR, Mannick JA, Rodrick ML 1990 Circulating human peripheral blood granulocytes synthesize and secrete tumor necrosis factor. Proc Natl Acad Sci USA 87:6758-6761

5. Strieter RM, Kasahara K, Allen RM, Standiford TJ, Rolfe MW, Becker FS, Chensue SW, Kunkel SL 1992 Cytokine-induced neutrophil-derived interleukin-8. Am J Pathol 141:397-407

6. Cassatella MA, Gasperini S, Russo MP 1997 Cytokine expression and release by neutrophils. Ann NY Acad Sci 832:233-242

7. Yeaman GR, Collins JE, Currie JK, Guyre PM, Wira CR, Fanger MW 1998 IFN-gamma is produced by polymorphonuclear neutrophils in human uterine endometrium and by cultured peripheral blood polymorphonuclear neutrophils. J Immunol 160:5145-5153

8. Zentay Z, Sharaf M, Qadir M, Drafta D, Davidson D 1999 Mechanism for dexamethasone inhibition of neutrophil migration upon exposure to lipopolysaccharide in vitro: role of neutrophil interleukin-8 release. Pediatr Res 46:406-410

9. Barnes PJ, Karin M 1997 Nuclear factor- $\kappa$ B-a pivotal transcription factor in chronic inflammatory diseases. N Engl J Med 336:1066-1071

10. Blackwell TS, Christman JW 1997 The role of nuclear factor- $\kappa$ B in cytokine gene regulation. Am J Respir Cell Mol Biol 17:3-9

11. Christman JW, Lancaster LH, Blackwell TS 1998 Nuclear factor $\kappa$ B: a pivotal role in the systemic inflammatory response syndrome and new target for therapy. Intensive Care Med 24:1131-1138

12. Siebenlist U, Franzoso G, Brown K 1994 Structure, regulation, and function of NF- $\kappa$ B. Annu Rev Cell Biol 10:405-455

13. McDonald PP, Bald A, Cassatella MA 1997 Activation of the NF- $\kappa$ B pathway by inflammatory stimuli in human neutrophils. Blood 89:3421-3433

14. McDonald PP, Russo MP, Ferrini S, Cassatella MA 1998 Interleukin-15 induces NF- $\kappa$ B activation and IL-8 production in human neutrophils. Blood 92:4828-4835

15. Ward C, Chilvers ER, Lawson MF, Pryde JG, Fujihara S, Farrow SN, Haslett C, Rossi AG 1999 NF- $\kappa$ B activation is a critical regulator of human granulocyte apoptosis in vitro. J Biol Chem 274:4309-4318

16. Nick JA, Avdi NJ, Young SK, Lehman LA, McDonald PP, Frasch SC, Billstrom MA, Henson PM, Johnson GL, Worthen GS 1999 Selective activation and functional significance of $38 \alpha$ mitogen-activated protein kinase in lipopolysaccharide-stimulated neutrophils. J Clin Invest 103:851-858

17. Tan ND, Davidson D 1995 Comparative differences and combined effects of interleukin-8, leukotriene B4, and platelet-activating factor on neutrophil chemotaxis of the newborn. Pediatr Res 38:11-16

18. Dignam JD, Lebovitz RM, Roeder RG 1983 Accurate transcription initiation by RNA polymerase II in a soluble extract from isolated mammalian nuclei. Nucleic Acids Res 11:1475-1489

19. Carter TH, Vancurova I, Sun I, Lou W, DeLeon S 1990 A DNA-activated protein kinase from HeLa cell nuclei. Mol Cell Biol 10:6460-6471

20. Franzoso G, Bours V, Azarenko V, Park S, Tomita-Yamaguchi M, Kanno T, Brown K, Siebenlist U 1993 The oncoprotein Bcl-3 can facilitate NF- $\kappa$ B mediated transactivation by removing inhibiting p50 homodimers from select $\kappa \mathrm{B}$ sites. EMBO J 12:3893-3901

21. Baer M, Dillner A, Schwartz RC, Sedon C, Nedospasov S, Johnson PF 1998 Tumor necrosis factor alpha transcription in macrophages is attenuated by an autocrine factor that preferentially induces NF- $\kappa$ B p50. Mol Cell Biol 18:5678-5689

22. Ziegler-Heitbrock HWL, Wedel A, Schraut W, Strobel M, Wendelgass P, Sternsdorf T, Bauerle P, Haas JG, Riethmuller G 1994 Tolerance to lipopolysaccharide involves mobilization of nuclear factor $\kappa \mathrm{B}$ with predominance of p50 homodimers. J Biol Chem 269:17001-17004

23. Kastenbauer S, Ziegler-Heitbrock HWL $1999 \mathrm{NF}-\kappa \mathrm{B} 1$ (p50) is upregulated in lipopolysaccharide tolerance and can block tumor necrosis factor gene expression. Infect Immun 67:1553-1559

24. Contrino J, Krause PJ, Slover N, Kreutzer D 1993 Elevated interleukin-1 expression in human neonatal neutrophils. Pediatr Res 34:249-252

25. Karin M 1999 The beginning of the end: I $\kappa$ B kinase (IKK) and NF- $\kappa \mathrm{B}$ activation. J Biol Chem 274:27339-27342

26. Hay RT, Vuillard L, Desterro JMP, Rodriguez MS 1999 Control of NF- $\kappa$ B transcriptional activation by signal induced proteolysis of $\mathrm{I} \kappa \mathrm{B} \alpha$. Philos Trans R Soc Lond 354:1601-1609

27. Rodriguez MS, Thompson J, Hay RT, Dargemont C 1999 Nuclear retention of I $\kappa \mathrm{B} \alpha$ protects it from signal-induced degradation and inhibits NF- $\kappa \mathrm{B}$ transcriptional activation. J Biol Chem 274:9108-9115

28. Kilpinen S, Henttinen T, Lahdenpohja N, Hulkkonen J, Hurme M 1996 Signals leading to the activation of NF- $\kappa \mathrm{B}$ transcription factor are stronger in neonatal than adult T lymphocytes. Scand J Immunol 44:85-88

29. Allgaier B, Shi M, Luo D, Koenig JM 1998 Spontaneous and Fas-mediated apoptosis are diminished in umbilical cord blood neutrophils compared with adult neutrophils. J Leukoc Biol 64:331-336

30. Halliday HL 1999 Clinical trials of postnatal corticosteroids: inhaled and systemic. Biol Neonat 76:29-40

31. Merritt TA, Cochrane CG, Holcomb K, Bohl B, Hallman M, Strayer D, Edwards DK 1983 Elastase and alpha 1-proteinase inhibitor activity in tracheal aspirates during 
respiratory distress syndrome. Role of inflammation in the pathogenesis of bronchopulmonary dysplasia. J Clin Invest 72:656-666

32. Wertheim WA, Kunkel SL, Standiford TJ, Burdick MD, Becker FS, Wilke CA, Gilbert AR, Strieter RM 1993 Regulation of neutrophil-derived IL-8: the role of prostaglandin E2, dexamethasone, and IL-4. J Immunol 151:2166-2175

33. Cato AC, Wade E 1996 Molecular mechanisms of anti-inflammatory action of glucocorticoids. Bioessays 18:371-378

34. DiDonato JA, Saatcioglu F, Karin M 1996 Molecular mechanisms of immunosuppresssion and anti-inflammatory activities by glucocorticoids. Am J Respir Crit Care Med 154:S11-S15

35. Wissink S, Van Heerde EC, Van der Burg B, Van der Saag PT 1998 A dual mechanism mediates repression of NF- $\kappa \mathrm{B}$ activity by glucocorticoids. Mol Endocrinol 12:355-363

36. Auphan N, DiDonato JA, Rosette C, Helmberg A, Karin M 1995 Immunosuppression by glucocorticoids: inhibition of NF- $\kappa$ B activity through induction of $\mathrm{I} \kappa \mathrm{B}$ synthesis. Science 270:286-290
37. Scheinman RI, Cogswell PC, Lofquist AK, Baldwin AS 1995 Role of transcriptional activation of $\mathrm{I} \kappa \mathrm{B}$ in mediation of immunosuppression by glucocorticosteroids. Science 270:283-286

38. Ray A, Prefontaine KE 1994 Physical association and functional antagonism between the p65 subunit of transcription factor NF- $\kappa \mathrm{B}$ and the glucocorticoid receptor. Proc Natl Acad Sci USA 91:752-756

39. Brostjan C, Anrather J, Czizmadia V, Stroka D, Soares M, Bach FH, Winkler H 1996 Glucocorticoid-mediated repression of NF- $\kappa$ B activity in endothelial cells does not involve induction of $\mathrm{I} \kappa \mathrm{B} \alpha$ synthesis. J Biol Chem 271:19612-19616

40. Liden J, Delaunay F, Rafter I, Gustafson J, Okret S 1997 A new function for the C-terminal zinc finger of the glucocorticoid receptor. Repression of RelA transactivation. J Biol Chem 272:21467-21472

41. Heck S, Bender K, Kullmann M, Gottlicher M, Herrlich P, Cato ACB 1997 $\mathrm{I} \kappa \mathrm{B} \alpha$-independent downregulation of $\mathrm{NF}-\kappa \mathrm{B}$ activity by glucocorticoid receptor. EMBO J 16:4698-4707 